\title{
Metabolic Evaluation of Kidney Transplant Recipients for Stone Disease and Comparison with Healthy Controls and Stone Formers
}

\section{Böbrek Nakil Hastalarının Üriner Sistem Taş Hastalığı Olan ve Olmayan Gruplarla Karşılaştırılması ve Üriner Sistem Taş Hastalığı için Metabolik Değerlendirilmesi}

\author{
Serdar Savașçı, Yakup Bostancı, Ender Özden, Fatih Ataç, Șaban Sarikaya, Yarkın Kamil Yakupoğlu
}

Ondokuz Mayıs University Faculty of Medicine, Department of Urology, Samsun, Turkey

What's known on the subject? and What does the study add?

The metabolic effects of kidney transplantation and CNIs on stone formation remains unclear. Low levels of urinary citrate may lead to de novo stone formation in the transplant group in the longer follow-up. Low levels of urinary calcium, oxalate, phosphate, uric acid and high urine volumes may explain the no occurrence of stones in this cohort. CNIs might increase the metabolic susceptibility to stone formation besides their nephrotoxic effects in the kidney transplant population. However our data does not support routine citrate replacement therapy for preventing stone formation and minimizing the toxic effects of CNIs due to tubular acidosis.

\section{ABSTRACT}

Objective

The aim of this study was to determine the metabolic effects of kidney transplantation and calcineurin inhibitors (CNIs) on stone formation in the post-transplant period.

\section{Materials and Methods}

Forty kidney transplant recipients (KTRs) and 40 patients undergoing percutaneous nephrolithotomy (PNL) operation due to kidney stone disease between January 2002 and January 2010 were evaluated retrospectively. For control group 20 patients who neither had urinary stone disease (USD) nor a kidney transplant were chosen.

\section{Results}

No statistical difference was observed in terms of age, gender, body-mass index (BMI) and urinary pH between the groups. Twenty-four hour urine volume was significantly higher in the KTRs $(p=0.001)$. However 24 hour urinary oxalate, citrate, uric acid, sodium and calcium levels were lower in the KTRs when compared to two other groups ( $p=0.001, p=0.0001, p=0.004$, $p=0.046, p=0.017$, respectively). Twenty-four hour urinary potassium levels in the control group and the phosphorus levels in the group undergoing percutaneous nephrolithotomy were higher compared to other groups ( $p=0.022, p=0.008)$. After follow-up of $23.55 \pm 14(2-50)$ months none of the KTRs were diagnosed with a urinary stone.

\section{ÖZET}

Amaç

Böbrek nakli sonrası dönemde üriner sistem taş hastalığı gelişiminde böbrek nakli ve kalsinörin inhibitörlerinin metabolik etkilerinin araştırıması amaçlandı.

\section{Gereç ve Yöntem}

Ocak 2002 ve Ocak 2010 yılları arasında böbrek nakli yapılan 40 hasta ve üriner sistem taş hastalığı nedeniyle perkütan nefrolitotomi uygulanan 40 hasta retrospektif olarak değerlendirildi. Kontrol grubu olarak da çalışmaya üriner sistem taş hastalı̆ı̆ hikayesi olmayan ve böbrek nakli yapılmamış 20 hasta alındı.

\section{Bulgular}

Yaş, cinsiyet, vücut kitle indeksi ve idrar pH'leri açısından gruplar arası istatistiksel fark saptanmadı. Yirmi dört saatlik idrar volümleri nakil hastalarında belirgin yüksek bulundu $(p=0,001)$. Yirmi dört saatlik idrar oxalat, sitrat, ürik asit, sodyum ve kalsiyum düzeyleri nakil hastalarında diğer iki grupla karşılaştıııldığında daha düşük bulundu (sırasıyla $p=0,001, p=0,001$, $p=0,004, p=0,046, p=0,017$ ). Kontrol grubunda 24 saatlik idrar potasyum düzeyleri, perkütan nefrolitotomi uygulanan grupta da fosfor düzeyleri yüksek saptandı ( $p=0,022, p=0,008)$. Nakil hastalarının hiçbirinde $23,55 \pm 14$ (2-50) aylık izlem sonunda taş saptanmadı.

\section{Correspondence}

Yakup Bostancı MD, Ondokuz Mayıs University Faculty of Medicine, Department of Urology, Samsun, Turkey Phone: +90 36231219 19/2849 E-mail: dryakupbostan@yahoo.com Received: 16.01.2015 Accepted: 22.01.2015 


\begin{abstract}
Conclusion

Although no stones were detected in the transplant group, low levels of urinary citrate may lead to de novo stone formation in the longer follow-up. Low levels of urinary calcium, oxalate, phosphate, uric acid and increased urine volume may axplain the fact that no stone was detected in this group. CNIs may increase metabolic tendency to stone formation in addition to their nephrotoxic effects. However our data does not support routine citrate replacement therapy for preventing stone formation and minimizing the toxic effects of CNIs due to tubular acidosis.
\end{abstract}

\section{Key Words}

Kidney transplantation, calcineurin inhibitor, citrate, urinary system stone disease

\section{ÖZET}

\section{Sonuç}

İzlemde nakil hastalarında taş saptanmamasına rağmen uzun takiplerde düşük sitrat düzeyleri taş oluşumuna sebep olabilir. Ayrıca serimizde nakil grubundaki hastalarda idrar kalsiyum, oxalat, fosfat, ürik asit düzeylerinin düşük olması ve artmış idrar volümleri bu grupta taş saptanamamasını açıklayabilir. Nakil grubunda kalsinörin inhibitörleri, nefrotoksik etkilerinin yanında taş oluşumuna metabolik yatkınlığı artırabilirler. Ancak verilerimiz taş oluşumunu önlemek ve kalsinörin inhibitörlerinin nefrotoksik etkilerini azaltmak için rutin sitrat replasman tedavisini desteklememektedir.

\section{Anahtar Kelimeler}

Böbrek nakli, kalsinörin inhibitörü, sitrat, üriner sistem taş hastalığı

\section{Introduction}

Kidney stone formation in the allograft is a rare complication in the posttransplant period. Besides being nephrotoxic, calcineurin inhibitors (CNIs) which are commonly used as a maintenance immunosuppressive treatment in kidney transplant patients, display a negative role on mineral homeostasis. The mechanism of how CNIs play a role on excretion and concentration of lithogenic and urinary inhibitor substances in urine is still not clearly understood. In the posttransplant period CNIs can cause hyperkalemia, hyperoxaluria, hypercalciuria, hyperuricosuria, hypocitraturia and hypomagnesemia $(1,2)$.

Fewer occurrences of symptoms like renal colic and pain caused by stone in the transplant population may necessitate further attention for this population. There are very few studies evaluating the metabolic effects of kidney transplantation and CNIs on stone formation. This study was conducted to determine the metabolic effects of kidney transplantation and CNIs on stone formation in the posttransplant period. To our knowledge this is the first study evaluating the development of urinary stone disease (USD) risk factors after kidney transplantation in a Turkish population.

\section{Material and Methods}

This study was approved by the Ondokuz Mayıs University Medical Research Ethics Committee. Total of 100 patients were divided into 3 groups. Transplantation group consisted of 40 kidney transplant recipients (KTRs) who had received either a cadaveric or a living donor kidney transplant between October 2005 and January 2010 at our center and had stable graft function during evaluation who had completed a mean follow-up of $23.55 \pm 14$ (2-50) months. All KTRs were on triple immunosuppressive regimen mainly consisting of a CNI+mycophenolate mofetil (MMF) or mycophenolate sodium (MPS)+steroid (39 patients) and just 1 patient was on sirolimus+MMF+steroid. The stone group also consisted of 40 patients who had undergone percutaneous nephrolithotomy (PNL) at our center between January 2002 and September 2009. Data of those two groups of patients were retrospectively analyzed. The control group consisted of 20 patients who were referred to our outpatient clinic with various urinary tract symptoms rather than stone disease. In each group demographic features, clinical and laboratory data including age, gender, body-mass index (BMI), creatinine, urinalysis, ultrasounography, X-ray, 24-hour urine analysis $(\mathrm{pH}$, sodium, potassium, calcium, magnesium, phosphate, uric acid, creatinine, oxalate, citrate) were recorded. In transplant patients cause of kidney failure (unknown etiology 18, glomerular pathology 10, hypertension 8 and urologic diseases 4), date of surgery, additional systemic diseases and types of immunosuppressive medications were also recorded.

\section{Statistical Methods}

Statistical analysis was performed using SPSS, version 15 (SPSS, Chicago, IL). Data were expressed as mean \pm standard error. For nonparametric data Kruskall-Wallis and for parametric data Student-t tests were used. Chi-square test was used to compare ratios and differences with a $p$ value of less than .05 were considered statistically significant.

\section{Results}

Demographic and laboratory data of the patients are presented in Table 1. The mean age of patients in transplant, stone and control groups were $38.67 \pm 12.31$ (14-65), 44.52 \pm 9.93 (14-78), 39.71 \pm 12 (2378) years, respectively. There was no statistical difference in terms of mean ages between groups ( $p=0.075)$. Male to female ratio was $25 / 15$, $26 / 14,17 / 3$ in the KTRs, USD and the control groups respectively. Mean BMI was $25.91 \pm 3.69$ in the entire cohort and no statistical difference was observed in terms of age, gender and BMI between groups. Mean serum creatinine level $(1.21 \pm 0.48 \mathrm{mg} / \mathrm{dl})$ was higher in the KTRs than the other groups $(p=0.001)$. However 24 hour urinary creatinine levels was highest in the control group $(2124.4 \pm 793 \mathrm{mg} / \mathrm{d})(p=0.0001)$ and no significance was observed between $\mathrm{pH}$ values $(\mathrm{p}=0.302)$.

Fourty-four hour urinary metabolic evaluation results are given in Table 2. KTRs had the highest 24 hour urinary volume $(3682 \pm 1213 \mathrm{ml} / \mathrm{d})$ $(p=0.001)$. However daily urinary oxalate, citrate, uric acid, calcium and sodium levels were significantly lower in the KTRs compared to other groups respectively $(p=0.001, p=0.0001, p=0.004, p=0.017$, $p=0.046$ ). While the control group had the highest potassium levels $(p=0.022)$, USD patients had the highest phosphorus levels ( $p=0.008)$. No significant difference was observed between magnesium levels.

Mainly four metabolic abnormalities hypocitraturia, hyperoxaluria, hyperuricosuria and hypercalciuria were evaluated. 
The frequency of hypocitraturia was $92.5 \%, 45 \%$ and 35\% in the KTRs, USD and the control groups respectively. This was significant for the KTRs group ( $p=0.0001)$, however no difference was observed between USD and the control group in terms of hypocitraturia $(p=0.459)$.

Hyperoxaluria was most frequent in the USD group (55\%) and this was statistically prominent when compared to KTRs and the control group respectively $(p=0.003, p=0.028)$. The frequency of hyperoxaluria was similar between the KTRs (23\%) and the control group (25\%) $(p=0.829)$.

Hyperuricosuria frequency in an ascending fashion was 5\%, 27.5\% and $30 \%$ in the KTRs, USD and the control group respectively. While USD and the control group were similar, the KTRs group had a significantly lower hyperuricosuria frequency ( $p=0.006, p=0.007$ respectively).

In the USD group, the frequency of hypercalciuria was significantly higher than the transplant group ( $20 \%$ vs. $5 \%)(p=0.043)$. Although control group had a 15\% hypercalciuria frequency no significance was detected between the KTRs and the USD.

None of the KTRs were found to have USD either with a KUB or USG and no stone related events were recorded during follow-up.

\section{Discussion}

After a successful kidney transplant, development of USD is a very rare condition and the incidence was reported to be $0.4-6 \%$ in adults $(3,4)$. Possible explanations for this include combination of careful donor screening, the denervated condition of the allograft kidney which would mask renal colic, and early loss of concentrating ability leading to polyuria (5).
In a large retrospective cohort study Abbot et al. reported, 52 (incidence density=69/100000 person years) patients who were hospitalized with a primary diagnosis of nephrolithiasis out of 39628 KTRs who were followed with a median of 1.91 years (6). No kidney stones were detected in our study; this might be due to limited number of patients and follow-up.

USD has a multifactorial etiology, major ones are; hyperparathyroidism, hypercalciuria, hypocitraturia, renal tubular acidosis, low urinary $\mathrm{pH}$, recurrent urinary tract infections, ureteral obstruction, vesicoureteral reflux and foreign bodies (2). Imbalance between urinary excretion and concentration of lithogenic and inhibitor substances plays an important role on stone formation; however there are not adequate number of studies evaluating those factors in kidney transplant population (7).

One of the most important results of our study was the high incidence of hypocitraturia (92.5\%) observed in the KTRs which is more than 2 -fold access than the USD and the control groups. Stapenhorst et al. has reported 79\% of hypocitraturia in $53 \mathrm{KTRs}$ (75\% of patients with Cyclosporin A (CsA) and 88\% of those with tacrolimus) (2). In addition to $\mathrm{CNI}$ consumption, higher incidence of hypocitraturia observed in our cohort might be explained by the endemic localization of Turkey regarding USD.

Renal tubular acidosis (RTA) developing in the allograft kidney due to various factors, such as ischemic injury during transplantation, tubulotoxic side effects of CNIs or chronic rejection is the major cause of hypocitraturia by increasing the citrate reabsorption from the proximal tubules to compensate intracellular acidosis. Additionally acidic urinary $\mathrm{pH}$ levels leads to a lesser degree of calcium-citrate

Table 1. Demographics and laboratory results of patients

\begin{tabular}{|c|c|c|c|c|}
\hline & KTRs & USD & Control & $p$ \\
\hline Number of patients (n) & 40 & 40 & 20 & \\
\hline Age (year) & $38.67 \pm 12.31$ & $44.52 \pm 9.93$ & $39.71 \pm 12$ & 0,075 \\
\hline Gender (M/F) & $25 / 15$ & $26 / 14$ & $17 / 3$ & 0,185 \\
\hline BMI $\left(\mathrm{kg} / \mathrm{m}^{2}\right)$ & $26.34 \pm 4.11$ & $26.26 \pm 3.80$ & $24.36 \pm 1.89$ & 0.111 \\
\hline Serum Creatinine (mg/dl) & $1.21 \pm 0.48$ & $0.93 \pm 0.25$ & $0.83 \pm 0.13$ & 0.001 \\
\hline Creatinine (24 hr urine) & $1297.1 \pm 524.5$ & $1418.6 \pm 872.4$ & $2142.4 \pm 793$ & 0.0001 \\
\hline pH (24 hr urine) & $5.32 \pm 0.43$ & $5.5 \pm 0.56$ & $5.32 \pm 0.40$ & 0.302 \\
\hline
\end{tabular}

Table 2. Fourty-four hour urinary metabolic evaluation results

\begin{tabular}{|c|c|c|c|c|}
\hline & KTRs & USD & Control group & $\mathrm{p}$ \\
\hline Oxalate (mg/d) & $32.1 \pm 21.2$ & $56.7 \pm 26$ & $42.1 \pm 13$ & 0.001 \\
\hline Citrate $\left(\mathrm{mg} / 1.73 \mathrm{~m}^{2} / \mathrm{d}\right)$ & $108.7 \pm 78.4$ & $425 \pm 317$ & $479 \pm 298$ & 0.0001 \\
\hline Uric acid (mg/d) & $471 \pm 207$ & $795 \pm 1472$ & $717 \pm 279$ & 0.004 \\
\hline Sodium (mg/d) & $1496 \pm 350$ & $1994 \pm 576$ & $1815 \pm 576$ & 0.046 \\
\hline Calcium (mg/d) & $114 \pm 99.1$ & $189 \pm 163$ & $178.84 \pm 89$ & 0.017 \\
\hline Potassium (mg/d) & $462 \pm 196$ & $444 \pm 209$ & $628 \pm 237$ & 0.022 \\
\hline Phosphorus (mg/d) & $699 \pm 289$ & $921 \pm 215$ & $682 \pm 222$ & 0.008 \\
\hline Magnesium (mg/d) & $37.7 \pm 18.3$ & $40.4 \pm 20.4$ & $50.2 \pm 19.07$ & 0.83 \\
\hline Urine volume $(\mathrm{ml} / \mathrm{d})$ & $3682 \pm 1213$ & $1997 \pm 736$ & $1810 \pm 444$ & 0.001 \\
\hline
\end{tabular}


binding (2). In an experimental animal model Melnick et al. have shown that, CsA lowers urinary citrate levels irrespective of acidosis or hypokalemia (8).

Furthermore, ACE inhibitors are known to cause hypocitraturia (9). However none of the KTRs in our study was receiving ACE inhibitors.

Besides hypocitraturia, hyperoxaluria and hypercalciuria puts KTRs under risk for development of nephrocalcinosis and USD by leading urinary supersaturation. However urinary saturation of oxalate and calcium was least elevated in KTRs, possibly due to increased daily urinary volume $(>3 \mathrm{~L} / \mathrm{d})$.

CsA is known to cause hypercalciuria by increasing both bone turnover and decreasing urinary ammonium excretion which leads to RTA. Developing intracellular acidosis is compensated by increased proximal tubular citrate reabsorption which leads to significant hypocitraturia. Citrate, binds calcium in the tubular lumen and forms a nondissociable but soluble complex, so insoluble calcium oxalate crystals cannot be developed (10). On the other hand, the transplant patients have reduced kidney function compared to the other groups which could be the cause of the low citrate and calcium excretion.

In our study 24 hour urinary calcium levels were significantly lower in KTRs than the other groups. This finding is in conflict with the previously reported CNI induced hypercalciuria data. However 5 KTRs in our study had a history of parathyroidectomy and low levels of urinary sodium observed in this group might explain the lower frequency of hypercalciuria observed in KTRs.

CNIs are closely related to hypermagnesuria, hypercalciuria and hypomagnesemia. In a rat model Nijenhuis et al found that tacrolimus causes downregulation of specific calcium and magnesium transport proteins provides a molecular mechanism for tacrolimus induced hypercalciuria and hypomagnesaemia (11). Amaro et al. reported urinary metabolic evaluation results of 182 USD patients which revealed 21\% of hypomagnesuria. Decreased excretion of magnesium is a potential risk factor for development of calcium stones. Magnesium supplements are useful for the prevention or reducing the number of recurrences of calcium stones. However due to lower renal threshold of magnesium, desired efficacy may not be achieved. In the same study hyperuricosuria was reported in $20 \%$ of the patients (12). Although no statistical significance was observed, urinary magnesium levels were lower in the KTRs in our study. This result is also in contrast with the literature data regarding CNI induced hypermagnesuria (13).

Major elimination route of oxalate is via kidneys and dialysis can only remove an inadequate amount of the daily oxalate intake, the serum level of oxalate in end stage renal disease patients is progressively increased. After a successful kidney transplant large amount of oxalate is excreted into the urine and serum oxalate levels normalizes rapidly almost in all patients except those who have primary oxaluria $(14,15)$. Truong et al. has reported calcium oxalate deposition in 13 out of $315(4 \%)$ renal transplant biopsies from 9 patients and has concluded that calcium oxalate deposition in renal allografts is rather unusual and can be classified in different categories with distinctive morphologic features and clinical implications (16). Also, Dumoulin et al. reported no increase in urinary calcium oxalate supersaturation in long-term kidney transplant recipients, which is universally accepted as one mechanism of stone formation (17). This may explain the low levels of urinary oxalate observed in KTRs compared to other groups in our study.
Supersaturation of urinary uric acid is required for uric acid stone formation. Three factors contribute to this variable: low urine $\mathrm{pH}$, hyperuricosuria, and low urinary volume (18). Hyperuricosuria may be associated with hyperuricemia. CNIs such as cyclosporine and tacrolimus are known to cause hyperuricemia relatively frequently (19). Possible mechanism is increased proximal tubular urate reabsorption, or decreased urate secretion (20). In the absence of concomitant increased synthesis of uric acid, increasing urate reabsorption may account for hyperuricemia, but it would not be expected to account for hyperuricosuria. Cantarell et al. reported 3\% of USD occurrence among 3\% of 365 KTRs and at equal rates in the groups of patients prescribed azathioprine or CsA. Among the patients receiving azathioprine, however, all stones were composed of calcium salts. Among patients receiving CsA, on the other hand $60 \%$ of stones were composed of uric acid. Patients on CsA had a lower average urinary $\mathrm{pH}$, higher serum uric acid levels and lower urate clearance and urate fractional rate compared to those on azathioprine (21). However Klingler et al. reported only $0.2 \%$ (2 of 1027) of all KTRs had documented uric acid stones which they wouldn't expect any lithogenic effect of CsA (5). In our cohort only 5\% of KTRs were found to have hyperuricosuria which was significantly lower than the USD and the control groups, also no significance was observed between urinary $\mathrm{pH}$ values between groups. Also the higher fluid intake resulting in higher urinary volume in these patients may have had some influence in respect to stone formation, which has been previously reported by Borghi et al. Occurence of no stones in our series may even support their findings (22).

Greater amount of inorganic phosphorus is reabsorbed from the proximal tubules with sodium after being filtrated by the glomerulus. Increased parathyroid hormone levels, relative calcitriole deficiency, glucocorticoids and CsA consumption have a negative impact on tubular phosphorus reabsorption. Large amount of hypophosphatemia caused by renal phosphate loss occurs frequently after kidney transplantation (23). Falkiewicz et al. has demonstrated that tacrolimus is faster than CsA for correcting the tubular phosphorus reabsorption impairment (24). Large amount of phosphorus found in urine is a risk factor for the development of USD (25). In our study lower levels of phosphorus observed in KTRs may be attributed to tacrolimus based regimens prescribed in most of the KTRs.

\section{Conclusion}

This study led us to conclude that although there are many metabolic risks for stone formation in KTRs we were not able to show de novo occurrence of urinary stones in this population. Low levels of urinary calcium, oxalate, phosphate and uric acid and high urine volumes may explain the no occurrence of stones in this cohort. Although no stones were detected in the transplant group, low levels of urinary citrate may lead to de novo stone formation in the longer followup. However our data does not support routine citrate replacement therapy for preventing stone formation and minimizing the toxic effects of CNIs due to tubular acidosis. A longer term follow up, however, will be needed to quantify this.

\section{Conflict of interest}

There are no conflicts of interest. 


\section{References}

1. Naesens $M$, Kuypers $D R$, Sarwal M. Calcineurin inhibitor nephrotoxicity. Clin J Am Soc Nephrol 2009;4:481-508.

2. Stapenhorst L, Sassen R, Beck B, Laube N, Hesse A, Hoppe B. Hypocitraturia as a risk factor for nephrocalcinosis after kidney transplantation. Pediatr Nephrol 2005;20:652-656.

3. Stravodimos KG, Adamis S, Tyritzis S, Georgios Z, Constantinides CA. Renal transplant lithiasis: analysis of our series and review of the literature. J Endourol 2012;26:38-44.

4. Khositseth S, Gillingham KJ, Cook ME, Chavers BM. Urolithiasis after kidney transplantation in pediatric recipients: a single center report. Transplantation 2004;78:1319-1323.

5. Klingler HC, Kramer G, Lodde $\mathrm{M}$, Marberger M. Urolithiasis in allograft kidneys. Urology 2002;59:344-348.

6. Abbott KC, Schenkman N, Swanson SJ, Agodoa LY. Hospitalized nephrolithiasis after renal transplantation in the United States. Am J Transplant 2003;3:465-470.

7. Harper JM, Samuell CT, Hallson PC, Wood SM, Mansell MA. Risk factors for calculus formation in patients with renal transplants. $\mathrm{Br} J$ Urol 1994;74:147-150.

8. Melnick JZ, Chang HY. Cyclosporine decreases urinary citrate in rats independent of acidosis or hypokalemia. J Am Soc Nephrol 1998;9:712A.

9. Melnick JZ, Preisig PA, Haynes S, Pak CY, Sakhaee K, Alpern RJ. Converting enzyme inhibition causes hypocitraturia independent of acidosis or hypokalemia. Kidney Int 1998;54:1670-1674.

10. Simpson DP. Citrate excretion: a window on renal metabolism. Am J Physiol 1983;244:F223.

11. Nijenhuis T, Hoenderop JG, Bindels RJ. Downregulation of $\mathrm{Ca}(2+)$ and $\mathrm{Mg}(2+)$ transport proteins in the kidney explains tacrolimus (FK506)induced hypercalciuria and hypomagnesemia. J Am Soc Nephrol 2004;15:549-557.

12. Amaro CR, Goldberg J, Amaro JL, Padovani CR. Metabolic assessment in patients with urinary lithiasis. Int Braz J Urol 2005;31:29-33.

13. Chang CT, Hung CC, Tian YC, Yang CW, Wu MS. Ciclosporin reduces paracellin-1 expression and magnesium transport in thick ascending limb cells. Nephrol Dial Transplant 2007;22:1033-1040.
14. Worcester EM, Fellner SK, Nakagawa Y, Coe FL. Effect of renal transplantation on serum oxalate and urinary oxalate excretion. Nephron 1994;67:414-418.

15. Hoppe B, Kemper MJ, Bokenkamp A, Portale AA, Cohn RA, Langman CB. Plasma calcium oxalate supersaturation in children with primary hyperoxaluria and end-stage renal failure. Kidney Int 1999;56:268-274.

16. Truong LD, Yakupoglu U, Feig D, Hicks J, Cartwight J, Sheikh-Hamad D, Suki WN. Calcium oxalate deposition in renal allografts: morphologic spectrum and clinical implications. Am J Transplant 2004;4:1338-1344.

17. Dumoulin G, Hory B, Nguyen NU, Henriet MT, Bresson C, Bittard $H$, Saint-Hillier $Y$, Regnard J. Lack of increased urinary calcium-oxalate supersaturation in long-term kidney transplant recipients. Kidney Int 1997;51:804-810.

18. Shekarriz B, Stoller ML. Uric acid nephrolithiasis: current concepts and controversies. J Urol 2002;168:1307-1314.

19. Luke PP, Jordan ML. Contemporary immunosuppression in renal transplantation. Urol Clin North Am 2001;28:733-750.

20. Laine J, Holmberg C. Mechanisms of hyperuricemia in cyclosporinetreated renal transplanted children. Nephron 1996;74:318-323.

21. Cantarell MC, Capdevila L, Morlans M, Piera L. Uric acid calculus in renal transplant patients treated with cyclosporine. Clin Nephrol 1991;35:288.

22. Borghi L, Meschi T, Amato F, Briganti A, Novarini A, Giannini A. Urinary volume, water and recurrences in idiopathic calcium nephrolithiasis: a 5-year randomized prospective study. J Urol 1996;155:839-843.

23. Levi M. Post-transplant hypophosphatemia. Kidney Int 2001;59:23772387.

24. Falkiewicz $K$, Nahaczewska $W$, Boratynska $M$, Owczarek $H$, Klinger $M$, Kaminska D, Wozniak M, Szepietowski T, Patrzalek D. Tacrolimus decreases tubular phosphate wasting in renal allograft recipients. Transplant Proc 2003;35:2213-2215.

25. Williams CP, Child DF, Hudson PR, Soysa LD, Davies GK, Davies MG, De Bolla AR. Inappropriate phosphate excretion in idiopathic hypercalciuria: the key to a common cause and future treatment? J Clin Pathol 1996;49:881888. 